\section{Patient satisfaction following endoscopic endonasal dacryocystorhinostomy: a quality of life study}

\begin{abstract}
Purpose To assess the subjective success and quality of life of adult patients post endoscopic endonasal dacryocystorhinostomy (EE-DCR) for acquired nasolacrimal duct obstruction.

Design Retrospective, questionnaire study performed at least 6 months post EE-DCR.

Participants Hundred and ten of the 282 consecutive patients who underwent EE-DCR.

Methods A standardised questionnaire (Glasgow Benefit Inventory, GBI) was used to analyse the quality of life. The questionnaire examines four parameters, providing total, subscale, social, and physical scores.

Main outcome measures We aimed to assess patient experience following EE-DCR surgery. Total GBI scores range from $-\mathbf{1 0 0}$ to +100 , the former reflecting maximal negative benefit and corresponding to subjective worsening of tearing and impact on quality of life. Any positive score reflects a satisfactory surgical outcome and $+\mathbf{1 0 0}$ represents maximal positive benefit. A score of zero is no perceived benefit.
\end{abstract}

Oculoplastic and Orbital Service, The Western Eye Hospital, London, UK

Correspondence: JM Olver, Oculoplastic and Orbital Service, The Western Eye Hospital, 153-173 Marylebone Road, London NW1 5QH, UK. Tel: $+44(0) 2033126666$; Fax: + 44 (0)207 8863259 . E-mail: janeolver@aol.com

Received: 29 August 2012 Accepted in revised form: 23 March 2013 Published online: 12 July 2013
Results The average age was 62 years, $63 \%$ were female. In three of the parameters measured, there was a subjective improvement post surgery: subscale score 22.16 (95\% CI: 15.23-29.09), total score 15.04 (95\% CI: 9.74-20.35), and social support score 4.67 (95\% CI: 0.93-8.42). Physical health scored -4.47 (95\% CI: -10.25 to 1.32 ). Secondary analyses demonstrate no statistical significance with respect to outcome whether a trainee or consultant performed the procedure. Younger patients (under split median of 63.5) had a better total score 19.04 (95\% CI: 11.35-27.74) than those older than 63.5 years (11.04, 95\% CI: 3.61-18.47).
G Jutley, R Karim, N Joharatnam, S Latif, T Lynch and JM Olver
Discussion This study shows that EE-DCR gave patients improvement in quality of life, proven by a validated questionnaire. The mean total score of $\mathbf{1 5 . 0 4}$ found in our study compares with the 18.7 recorded by Feretis et al in 2009. Results were irrespective of the grade of surgeon, similar to the findings of Fayers et al for functional successes.

Conclusion This study supports the use of EE-DCR for the improvement of quality of life in adult patients.

Eye (2013) 27, 1084-1089; doi:10.1038/eye.2013.96; published online 12 July 2013

Keywords: patient satisfaction; postoperative; epiphora; endoscopic endonasal DCR;

Glasgow Benefit Inventory

\section{Introduction}

Epiphora impacts on quality of life in adult patients by causing blurred vision, spattered glasses, and sore skin. ${ }^{1,2}$ Tearing is socially embarrassing as it mimics the appearance of persistent crying. An important cause of epiphora is narrowing or occlusion of the nasolacrimal duct. ${ }^{3}$ Nasolacrimal duct blockage is circumvented by surgically creating an anastomosis between the lacrimal sac and nasal cavity above the site of occlusion, by either external dacryocystorhinostomy (DCR) or endoscopic endonasal dacryocystorhinostomy (EE-DCR). The external approach has remained the mainstay of treatment for over a century. ${ }^{4}$ With the advent of fibreoptic endoscopes utilising the principles of total internal reflection and the simultaneous use of a light pipe within the lacrimal sac to guide placement of the osteotomy, the endoscopic endonasal approach to DCR gained popularity from the 1990s. ${ }^{5}$ 
Using a laser to create the rhinostomy is outdated because of high rates of fibrosis secondary to charring, with mechanical approaches using a diamond bur showing greater successes. ${ }^{6,7}$

We offer all patients endoscopic endonasal surgery, with its advantages of no scar, shorter postoperative recovery, greater heamostasis, and shorter operating time. In this study, we aimed to measure the impact of EE-DCR on patients' quality of life, using the Glasgow Benefit Inventory (GBI).

Robinson et $a l^{8}$ developed the GBI, a postinterventional questionnaire to be used in otolaryngological (ORL) procedures. It is a validated questionnaire that is both sensitive to the change in health status due to a surgical procedure and patient orientated. It is comprised of 18 questions, each of which is based on a five-point Likert scale. ${ }^{8}$ The questions are specifically tailored to measure a change in health status, defined as the general perception of well-being (12 questions). Social and physical health parameters are also assessed, with three questions each. The total GBI scores from - 100 (maximal negative benefit), through zero (no change) to +100 (maximal positive benefit in health status). ${ }^{8}$ Any positive score represents patient satisfaction with the intervention. Robinson aimed to control response bias by having half the answers range from large improvement to large deterioration and the remaining half conversely. We applied the GBI to collect data for EE-DCR, as quality of life is a significant contributor to overall success of the procedure.

\section{Materials and methods}

A postal questionnaire was sent out retrospectively, at least 6 months post EE-DCR. The study was carried out in accordance with ethical guidelines of the Declaration of Helsinki with institutional ethics approval. Patients were listed for surgery based on clinical assessment (including syringing and probing), plus/minus radiological diagnosis with lacrimal scintigraphy. Those with nasolacrimal duct obstruction (NLDO) were offered EE-DCR surgery.

Endoscopic endonasal DCR was performed under general anaesthesia. All patients had the nasal mucosa decongested with Moffats solution, combination of $1 \mathrm{ml}$ adrenaline 1 in 1000, $2 \mathrm{ml}$ of $10 \%$ cocaine, and $2 \mathrm{ml}$ sodium bicarbonate. The lateral nasal wall was infiltrated with $1 \mathrm{ml}$ of $2 \%$ xylocaine (with 1 in 200000 adrenaline). The lacrimal crest was identified using a rigid $0^{\circ}$ and/or $30^{\circ}$ Hopkins endoscope. The nasal mucoperiosteoum over the frontal process of the maxilla and lacrimal bone was elevated. A Medtronic diamond bur was used to create the bony rhinostomy. A fibreoptic light pipe was inserted into the lacrimal sac, enabling visualisation and subsequent vertical incision of the sac and flaps with a keratome. An oscillating blade was used as needed to fashion mucosa. O'Donoghue tubes are inserted and knotted.

Theatre records and operation notes were reviewed, and demographic data collected. Patients were eligible for our study if they had a NLDO and were aged 18 and over. Exclusion criteria included patients undergoing external or laser procedures, revision procedures for failed primary surgical procedures, pregnancy and secondary acquired NLDO (such as from sarcoid or Wegener's granulomatosis), and those with obstruction at the canaliculi or common canaliculus.

Each patient was sent the GBI questionnaire, enclosed with an information leaflet, consent form, and a stamped addressed envelope (see Appendix). We gave patients a 3-month period to respond, after which they were called twice, once during the day and once in the evening. We entered the data into an excel database and statistical analysis was performed.

\section{Results}

The records of 282 consecutive patients who underwent EE-DCR surgery were analysed. We sent out 250 surveys, as 32 addresses were not available. Out of the responses, 14 were returned anonymously and hence we were unable to add demographic data.

We received 97 posted responses, 3 months from sending out the questionnaires, representing an overall response rate of $38.7 \%$. Three were incomplete and hence were not included in the analysis. We than rang all non-responders to improve the compliance rate, and overall were able to fill 16 further questionnaires over the phone, giving a total of 110 responders.

The mean age of patients, at surgery, was 62 years (95\% CI: 59.36-65.08), with a range of 18-94. Overall 63\% were female, $37 \%$ were male and $56 \%$ were British. From the 110 questionnaires analysed, the mean total score from the GBI was + 15.04 (95\% CI: 9.74-20.35). The general subscale score was +22.16 (95\% CI: 15.23-29.09). Social support scale resulted in a mean of $+4.67(95 \% \mathrm{CI}$ : 0.93-8.42) and physical health scored -4.47 (95\% CI: -10.25 to 1.32 ). Figure 1 shows box-plots of both total and subscale scores, when individual ratings are categorised as either plus or minus scores.

Table 1 shows a breakdown of the operating surgeon in all 110 procedures. A $t$-test was performed for rank of operator and showed that consultant only $(n=67)$ had a mean total score of 13.18 (95\% CI: 7.14-19.21). The other group included any patients who had a trainee operating on them (even if that was together with a consultant, $n=26)$ and had a mean of 20.82 (95\% CI: 9.12-32.54). This difference was not statistically significant $(P=0.2199)$, similar to functional successes noted by Fayers et al. ${ }^{2}$ 
a

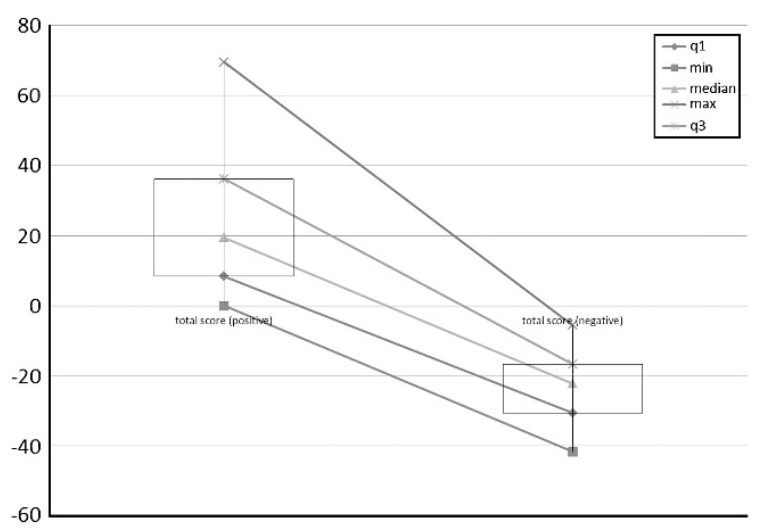

b

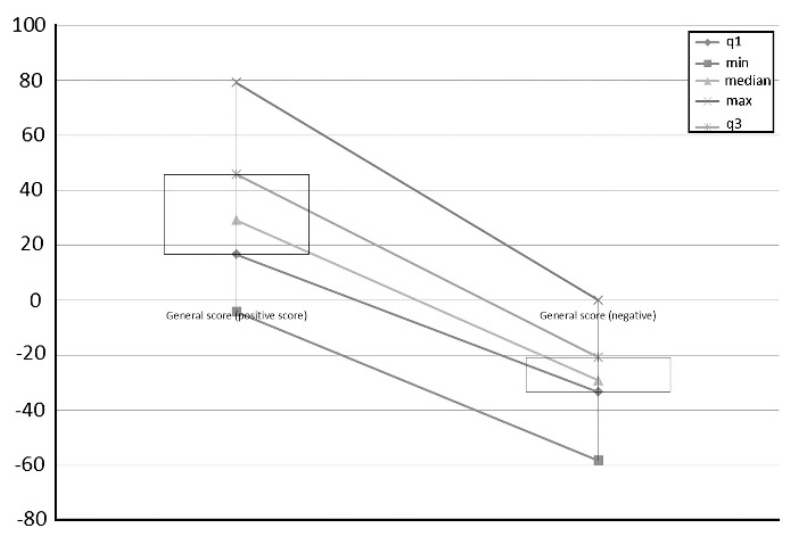

Figure 1 (a) Box plot of total scores. Total GBI scores, broken down into separate plus and minus scores. (b) Box plot of subscale scores. General GBI scores, broken down into separate plus and minus scores.

Table 1 Representation of all procedures performed by various operators

\begin{tabular}{lccc}
\hline & Performed & Success & Failure \\
\hline Consultant only & 51 & 43 & 8 \\
Consultant and trainee & 32 & 24 & 8 \\
Trainee only & 11 & 10 & 1 \\
Anonymously returned forms & 16 & 12 & 4 \\
\hline
\end{tabular}

Success is indicative of plus total scores.

A $t$-test for total score by patient age category was performed, split at the median of 63.5. The younger group's mean was 19.04 (95\% CI: 11.35-27.74), compared with 11.04 (95\% CI: 3.61-18.47) in the older group.

From undergoing surgery to receiving the questionnaire, there was a mean time of 47.01 months (with a range of 6-133).

\section{Discussion}

In this study, we have shown by using a validated tool that quality of life improves with EE-DCR. Modern medicine has moved full circle from the paternalistic approach practiced by previous generations. An important requirement of contemporary medicine is the patient experience: with particular emphasis on measuring the effect of an intervention on patient benefit. Vast improvements occurred in this area when Robinson et $a l^{8}$ devised the GBI, a validated questionnaire enabling assessment of the patients' health status post otolaryngeal or ophthalmic intervention.

We sent the questionnaires by mail, without seeing the patients. We aimed to avoid clinical bias from objective measures and use patient experience exclusively to assess the success of the procedure. To further highlight the importance of using the patients' experience as the primary outcome measure, Tarbet and Custer ${ }^{9}$ found that $62 \%$ of all patients with patent DCR's to irrigation still had persistent epiphora clinically. Furthermore, Delaney and Khooshabeh ${ }^{10}$ described only $38 \%$ of patients with patent DCRs clinically classed themselves as completely asymptomatic through questionnaire. It should be kept in mind that a significant number of these patients may represent epiphora of multifactorial cause.

We chose outcomes of at least 6 months postoperatively to assess success. $2,7,11$ Our response rate of $38.7 \%$ was markedly lower than other postal questionnaire studies for OLR procedures ${ }^{12,13}$ and most likely reflects our population of an inner city multi-cultural mix of patients, with $44 \%$ of the study population non-British. We found that the EE-DCR gave patients improvement in areas of general perception of well-being, including the social and psychological components contributing to health. The predominantly positive scores demonstrate that patients perceive EE-DCR as a beneficial procedure, with improvement in parameters including mucoid discharge, blurry vision, and soreness peri-orbitally from persistent wiping of the skin. Unlike the other three parameters, the mean physical health score was -4.47 . We were unable to fully account for this negative finding, but analysis of the GBI questionnaire shows that the questions enquiring about physical well-being are quite generic and relate to systemic health, with little correlation to the original symptoms (refer to questions 8, 12, and 16). Overall, as well as a lack of scarring, shorter operating time and minimal blood loss, EE-DCR now also receives positive feedback from validated patient assessments, giving credence to offering it as a first-line management of NLDO.

The ENT literature has published the use of questionnaires to assess patient symptoms post EE-DCR procedures, and authors have shown patient subjective improvement of symptoms. For instance Agarwal ${ }^{14}$ followed up 300 patients a year after EE-DCR and noted $94 \%$ were symptom free after the primary intervention. 
Validated quality of care data were not collected. Karim et $a l^{15}$ found $84 \%$ in the endoscopic cohort were symptom free at least 4 months postoperatively. Zenk et al ${ }^{16}$ gained a greater perspective into long-term symptom improvement, after performing a retrospective analysis of 165 patients who underwent EE-DCR. Total or partial resolution of symptoms, as described by patients, occurred in $81.8 \%$ (total resolution in $67.9 \%$ ).

The GBI has been used in a wide variety of ORL procedures, including rhinoplasty, ${ }^{17}$ acoustic neuroma surgery, ${ }^{18}$ endoscopic sinus surgery, ${ }^{12}$ and EE-DCR. ${ }^{1}$ Ho et $a l^{19}$ used the GBI questionnaire in a prospective study of 55 patients undergoing EE-DCR. The patients were reviewed at 6 months by a consultant ophthalmologist and graded as a success if the symptoms were either cured or better. Surgery was successful in $78 \%$ of patients; the mean total GBI scores for successful and failure groups were +34 and -19 , respectively (comparable with figures from our study of +23 and -24 ,

respectively). This study demonstrated that the GBI is a sensitive measure, as it can differentiate between success and failure. Most recently, Hii et al ${ }^{20}$ have prospectively evaluated adults treated with external or EE-DCR, analysing patient satisfaction with the GBI, economic cost, and surgical success. The study differed from ours as it was prospective, the authors aimed to compare the two procedures directly, and objective measures of success were also observed. Thirty-seven patients underwent external DCR and 40 were in the EE-DCR group. The questionnaire was posted 6 weeks postoperatively and the mean GBI scores were +16.1 and +24.1 , respectively. The difference of 8 between the scores did not reach statistical significance, ${ }^{20}$ suggesting that although both operations produce positive post-interventional change in health status, the difference between both is negligible. As anatomical and functional success at 3-month follow-up in both groups were similar (91.7 and $92.1 \%$ in the external and EE-DCR groups respectively) and the cost difference did not reach statistical difference, ${ }^{20}$ one can conclude that patient choice and surgeon preference key in deciding what approach is adopted. We feel the advantages of no scar, shorter postoperative recovery, greater heamostasis, and shorter operating time advocate the use of EE-DCR as front-line surgery, substantiated with the results from the Hii et $a l^{20}$ study showing no difference between the surgeries in three parameters.

In our study, we found that younger patients had statistically significant improved general perception of well-being compared with older patients. This is a consistent finding in the literature, for instance, Tripathi et $a l^{21}$ showed a statistical correlation between complete resolution 12 month post endoscopic laser DCR

(EL-DCR) in 46 patients and the younger the age of the patient. It is well recognised that the incidence of NLDO increases with age: it is plausible to consider that an 18 score questionnaire of the GBI could be difficult to fill in for our more elderly patients, particularly, if no guidance notes are presented to them. If a simpler questionnaire can be used, which is more user friendly, a more accurate assessment of patient symptomatology can be surmised. A Finnish group have recently devised a Nasolacrimal Duct Obstruction Symptom Score (NLDO-SS), and published their results following endoscopic DCR on 64 consecutive patients. ${ }^{22}$ The questionnaire had only five items that focused on the common ocular symptoms of NLDO, and as such it was more appropriate for nasolacrimal surgery than the GBI. The authors showed a statistically significant correlation between the GBI and the NLDO-SS: although not validated, perhaps the future step would be to use this simple and sensitive tool routinely to assess symptoms post EE-DCR in an ophthalmic setting.

Mistry et $a l^{23}$ questioned the use of GBI in assessing the success of EE-DCR. They argued that this is a quality of life assessment and patients with anatomical obstruction at the lacrimal apparatus may not have great overall disability. Furthermore, the GBI is intended to measure change in health status, yet it is only distributed post-procedure and thus is not appropriate for assessing symptoms before surgery. The authors developed a new Lac-Q questionnaire after reviewing the presenting complaints of 100 consecutive patients referred for treatment of lacrimal obstruction. The questions account for both eye-specific symptoms as well as the overall social impact of the disease. In a pilot study of 22 DCR surgeries, they showed that compared with preoperative scores, the reduction postoperatively was significant. ${ }^{23}$ Also noted was the correlation between Lac-Q scores and objective assessments, giving merit to the use of the questionnaire in a larger study.

Our study has all the limitations associated with being retrospective in nature. The range of time from surgery to receiving questionnaire was $6-133$ months and recall bias may have contributed to the results, even though the questionnaire used was validated. For future studies, the Lac-Q or NLDO-SS questionnaires can be used prospectively for patients undergoing EE-DCR.

\section{Conclusions}

EE-DCR can be considered the first-line surgical procedure for the treatment of acquired NLDO. As it improves quality of life, ophthalmologists should use measures such as GBI, Lac-Q, or NLDO-SS scores to evaluate success as an adjunct to auditing their results. Ultimately patients are not concerned with functional or anatomical outcome, but how an operation can help 
improve the quality of their life. Our study shows that EE-DCR gives an improvement of general well-being, as assessed by a validated questionnaire. This information should be made available to all patients before deciding their management options.

\section{Summary}

What was known before

- Limited knowledge about patient satisfaction post EE-DCR.

What this study adds

- We can use various questionnaires to improve our practice.

\section{Conflict of interest}

The authors declare no conflict of interest.

\section{References}

1 Feretis M, Newton JR, Ram B, Green F. Comparison of external and endonasal dacryocystorhinostomy. JLO 2009; 123: 315-319.

2 Fayers T, Laverde T, Tay E, Olver JM. Lacrimal surgery success after external dacryocystorhinostomy: functional and anatomical results using strict outcome criteria. Ophthal Plast Reconstr Surg 2009; 25(6): 473-475.

3 Olver JM. Colour Atlas of Lacrimal Surgery. 1st edn. Butterworth Heinemann Health: Oxford, UK, 2002, pp 30-37.

4 Toti A. Nuovo metodo conservatore di cura radicale delle suppurazioni croniche del sacco lacrimale. L Clin Mod 1904; 10: 385-387.

5 Massaro BM, Gonnering RS, Harris GJ. Endonasal laser dacryocystorhinostomy. A new approach to nasolacrimal duct obstruction. Arch Ophthalmol 1990; 108: 1172-1176.

6 Yung MW, Hardman-Lea S. Analysis of the results of surgical endoscopic dacryocystorhinostomy: effect of the level of obstruction. Br J Ophthalmol 2002; 86: 792-794.

7 Moore WMH, Bentley CR, Olver JM. Functional and anatomic results after two types of endoscopic endonasal dacryocystorhinostomy: surgical and holmium laser. Ophthalmology 2002; 109(8): 1575-1582.

8 Robinson K, Gatehouse S, Browning GG. Measuring patient benefit from otorhinolaryngological surgery and therapy. Ann Otol Rhinol Laryngol 1996; 105(6): 415-422.

9 Tarbet KJ, Custer PL. External dacryocystorhinostomy: surgical success, patient satisfaction and economic cost. Ophthalmology 1995; 102: 1065-1070.

10 Delaney YM, Khooshabeh R. Fluorescein transit test time and symptomatic outcomes after external dacryocystorhinostomy. Ophthal Plast Reconstr Surg 2002; 18(4): 281-284.

11 Olver JM. The success rates for endonasal dacryocystorhinostomy. Br J Ophthalmol 2003; 87: 1431.

12 Salhab M, Matai V, Salam MA. The impact of functional endoscopic sinus surgery on health status. Rhinology 2004; 42(2): 98-102.
13 Kanatas AN, Mehanna HM, Lowe D, Rogers SN. A second national survey of health-related quality of life questionnaires in head and neck oncology. Ann R Coll Surg Engl 2009; 91(5): 420-425.

14 Agarwal S. Endoscopic dacryocystorhinostomy for acquired nasolacrimal duct obstruction. I Laryn Otol 2009; 123: 1226-1228.

15 Karim R, Ghabrial R, Lynch T, Tang B. A comparison of external and endoscopic dacryocystorhinostomyfor acquired nasolacrimal duct obstruction. Clin Ophthalmol 2011; 5: 979-989.

16 Zenk J, Karatzanis AD, Psychogios G, Franzke K, Koch M, Hornung $\mathrm{J}$ et al. Long term results of endonasal dacryocystorhinostomy. Eur Arch Otorhinolaryngol 2009; 266: 1733-1738.

17 McKiernan DC, Banfield G, Kumar R, Hinton AE. Patient benefit from functional and cosmetic rhinoplasty. Clin Otolaryngol Allied Sci 2001; 26(1): 50-52.

18 Fahy C, Nikolopoulos TP, O'Donoghue GM. Acoustic neuroma surgery and tinnitus. Eur Arch Otorhinolaryngol 2002; 259(6): 299-301.

19 Ho A, Sachidananda R, Carrie S, Neoh C. Quality of life assessment after non-laser endonasal dacryocystorhinostomy. Clin Otolaryngol 2006; 31: 399-403.

20 Hii BW, McNab AA, Friebel JD. A comparison of external and endonasal dacryocystorhinostomy in regard to patient satisfaction and cost. Orbit 2012; 31(2): 67-76.

21 Tripathi A, Lesser THJ, O'Donnell NP, White S. Local anaesthetic endonasal endoscopic laser dacryocystorhinostomy: analysis of patients' acceptability and various factors affecting the success of this procedure. Eye 2002; 16: 146-149.

22 Smirnov G, Tuomilehto H, Kokki H, Kemppainen T, Kiviniemi V, Nuutinen J et al. Symptom score questionnaire for nasolacrimal duct obstruction in adults-a novel tool to assess the outcome after endoscopic dacryocystorhinostomy. Rhinology 2010; 48(4): 446-451.

23 Mistry N, Rockley TJ, Reynolds T, Hopkins C. Development and validation of a symptom questionnaire for recording outcomes in adult lacrimal surgery. Rhinology 2011; 49: 538-545.

\section{Appendix}

\section{The GBI questionnaire}

1. Has the result of the operation/intervention*affected the things you do?

\begin{tabular}{|c|c|c|c|c|}
\hline $\begin{array}{l}\text { Much } \\
\text { worse }\end{array}$ & $\begin{array}{l}\text { A little or } \\
\text { somewhat } \\
\text { worse }\end{array}$ & $\begin{array}{l}\text { No } \\
\text { change }\end{array}$ & $\begin{array}{l}\text { A little or } \\
\text { somewhat } \\
\text { better }\end{array}$ & $\begin{array}{l}\text { Much } \\
\text { better }\end{array}$ \\
\hline 1 & 2 & 3 & 4 & 5 \\
\hline
\end{tabular}

2. Have the results of the operation/intervention* made your overall life better or worse?

\begin{tabular}{|c|c|c|c|c|}
\hline $\begin{array}{l}\text { Much } \\
\text { better }\end{array}$ & $\begin{array}{l}\text { A little or } \\
\text { somewhat }\end{array}$ & $\begin{array}{l}\text { No } \\
\text { change } \\
\text { better }\end{array}$ & $\begin{array}{l}\text { A little or } \\
\text { somewhat }\end{array}$ & $\begin{array}{l}\text { Much } \\
\text { worse } \\
\text { worse }\end{array}$ \\
\hline 5 & 4 & 3 & 2 & 1 \\
\hline
\end{tabular}


3. Since your operation/intervention*, have you felt more or less optimistic about the future?

\begin{tabular}{|llllc|}
\hline $\begin{array}{l}\text { Much more } \\
\text { optimistic }\end{array}$ & $\begin{array}{l}\text { More } \\
\text { optimistic }\end{array}$ & $\begin{array}{l}\text { No } \\
\text { change }\end{array}$ & $\begin{array}{l}\text { Less } \\
\text { optimistic }\end{array}$ & $\begin{array}{c}\text { Much less } \\
\text { optimistic }\end{array}$ \\
5 & 4 & 3 & 2 & 1 \\
\hline
\end{tabular}

4. Since your operation/intervention*, do you feel more or less embarrassed when with a group of people?

$\begin{array}{llccc}\begin{array}{l}\text { Much more } \\ \text { embarrassed }\end{array} & \begin{array}{l}\text { More } \\ \text { embarrassed }\end{array} & \begin{array}{l}\text { No } \\ \text { change }\end{array} & \begin{array}{c}\text { Less } \\ \text { embarrassed }\end{array} & \begin{array}{c}\text { Much less } \\ \text { embarrassed }\end{array} \\ 1 & 2 & 3 & 4 & 5\end{array}$

5. Since your operation/intervention*, do you have more or less selfconfidence?

\begin{tabular}{|ccccc|}
\hline $\begin{array}{c}\text { Much more } \\
\text { self-confidence }\end{array}$ & $\begin{array}{c}\text { More self- } \\
\text { confidence }\end{array}$ & $\begin{array}{c}\text { No } \\
\text { change }\end{array}$ & $\begin{array}{c}\text { Less self- } \\
\text { confidence }\end{array}$ & $\begin{array}{c}\text { Much less } \\
\text { self- confidence }\end{array}$ \\
5 & 4 & 3 & 2 & 1 \\
\hline
\end{tabular}

6. Since your operation/intervention*, have you found it easier or harder to deal with company?

\begin{tabular}{|ccccc|}
\hline $\begin{array}{c}\text { Much } \\
\text { easier } \\
5\end{array}$ & Easier & $\begin{array}{c}\text { No } \\
\text { change }\end{array}$ & Harder & $\begin{array}{c}\text { Much } \\
\text { harder } \\
1\end{array}$ \\
& 4 & 3 & 2 & \\
\hline
\end{tabular}

7. Since your operation/intervention*, do you feel that you have more or less support from your friends?

\begin{tabular}{|ccccc|}
\hline $\begin{array}{c}\text { Much } \\
\text { more support }\end{array}$ & $\begin{array}{c}\text { More } \\
\text { support }\end{array}$ & $\begin{array}{c}\text { No } \\
\text { change }\end{array}$ & $\begin{array}{c}\text { Less } \\
\text { support }\end{array}$ & $\begin{array}{c}\text { Much } \\
\text { less support }\end{array}$ \\
5 & 4 & 3 & 2 & 1 \\
\hline
\end{tabular}

8. Have you been to your family doctor, for any reason, more or less often, since your operation/intervention*?

$\begin{array}{ccccc}\begin{array}{c}\text { Much more } \\ \text { often }\end{array} & \begin{array}{c}\text { More } \\ \text { often }\end{array} & \begin{array}{c}\text { No } \\ \text { change }\end{array} & \begin{array}{c}\text { Less } \\ \text { often }\end{array} & \begin{array}{c}\text { Much less } \\ \text { often }\end{array} \\ 1 & 2 & 3 & 4 & 5\end{array}$

9. Since your operation/intervention*, do you feel more or less confident about job opportunities?

\begin{tabular}{|ccccc|}
\hline $\begin{array}{c}\text { Much } \\
\text { more confident }\end{array}$ & $\begin{array}{c}\text { More } \\
\text { confident }\end{array}$ & $\begin{array}{c}\text { No } \\
\text { change }\end{array}$ & $\begin{array}{c}\text { Less } \\
\text { confident }\end{array}$ & $\begin{array}{c}\text { Much } \\
\text { less } \\
\text { confident } \\
1\end{array}$ \\
\hline
\end{tabular}

\begin{tabular}{|c|c|c|c|c|}
\hline $\begin{array}{l}\text { 10. Since your } \\
\text { conscious? }\end{array}$ & eration/inter & ion*, & feel more & or less sel \\
\hline $\begin{array}{c}\text { Much more } \\
\text { self-conscious }\end{array}$ & $\begin{array}{l}\text { More self- } \\
\text { conscious }\end{array}$ & $\begin{array}{c}\text { No } \\
\text { change }\end{array}$ & $\begin{array}{l}\text { Less self- } \\
\text { conscious }\end{array}$ & $\begin{array}{c}\text { Much less } \\
\text { self- } \\
\text { conscious }\end{array}$ \\
\hline 1 & 2 & 3 & 4 & 5 \\
\hline
\end{tabular}

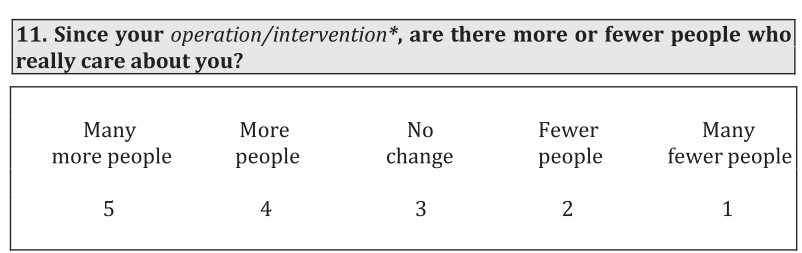

12. Since you had the operation/intervention*, do you catch colds or infections more or less often?

\begin{tabular}{ccccc}
$\begin{array}{c}\text { Much more } \\
\text { often }\end{array}$ & $\begin{array}{c}\text { More } \\
\text { often }\end{array}$ & $\begin{array}{c}\text { No } \\
\text { change }\end{array}$ & $\begin{array}{c}\text { Less } \\
\text { often }\end{array}$ & $\begin{array}{c}\text { Much less } \\
\text { often }\end{array}$ \\
1 & 2 & 3 & 4 & 5 \\
\hline
\end{tabular}

13. Have you had to take more or less medicine for any reason, since your operation/intervention*?

\begin{tabular}{ccccc}
$\begin{array}{c}\text { Much more } \\
\text { medicine }\end{array}$ & $\begin{array}{c}\text { More } \\
\text { medicine }\end{array}$ & $\begin{array}{c}\text { No } \\
\text { change }\end{array}$ & $\begin{array}{c}\text { Less } \\
\text { medicine }\end{array}$ & $\begin{array}{c}\text { Much less } \\
\text { medicine }\end{array}$ \\
1 & 2 & 3 & 4 & 5 \\
\hline
\end{tabular}

14. Since your operation/intervention*, do you feel better or worse about yourself?

\begin{tabular}{|ccccc|}
\hline $\begin{array}{c}\text { Much } \\
\text { better }\end{array}$ & Better & $\begin{array}{c}\text { No } \\
\text { change }\end{array}$ & Worse & $\begin{array}{c}\text { Much } \\
\text { worse }\end{array}$ \\
5 & 4 & 3 & 2 & 1 \\
\hline
\end{tabular}

15. Since your operation/intervention*, do you feel that you have had more or less support from your family?

\begin{tabular}{|ccccc|}
\hline $\begin{array}{c}\text { Much more } \\
\text { support }\end{array}$ & $\begin{array}{c}\text { More } \\
\text { support }\end{array}$ & $\begin{array}{c}\text { No } \\
\text { change }\end{array}$ & $\begin{array}{c}\text { Less } \\
\text { support }\end{array}$ & $\begin{array}{c}\text { Much less } \\
\text { support }\end{array}$ \\
5 & 4 & 3 & 2 & 1 \\
\hline
\end{tabular}

16. Since your operation/intervention*, are you more or less inconvenienced by your health* problem?

\begin{tabular}{|ccccc|}
$\begin{array}{c}\text { Much more } \\
\text { inconvenienced }\end{array}$ & $\begin{array}{c}\text { More } \\
\text { inconvenienced }\end{array}$ & $\begin{array}{c}\text { No } \\
\text { change }\end{array}$ & $\begin{array}{c}\text { Less } \\
\text { inconvenienced }\end{array}$ & $\begin{array}{c}\text { Much less } \\
\text { inconvenienced }\end{array}$ \\
1 & 2 & 3 & 4 & 5 \\
\hline
\end{tabular}

17. Since your operation/intervention*, have you been able to participate in more or fewer social activities?

\begin{tabular}{|ccccc|}
\hline $\begin{array}{c}\text { Many more } \\
\text { activities }\end{array}$ & $\begin{array}{c}\text { More } \\
\text { activities }\end{array}$ & $\begin{array}{c}\text { No } \\
\text { change }\end{array}$ & $\begin{array}{c}\text { Fewer } \\
\text { activities }\end{array}$ & $\begin{array}{c}\text { Many fewer } \\
\text { activities }\end{array}$ \\
5 & 4 & 3 & 2 & 1 \\
\hline
\end{tabular}

18. Since your operation/intervention*, have you been more or less inclined to withdraw from social situations?

\begin{tabular}{|ccccc|}
\hline $\begin{array}{c}\text { Much more } \\
\text { inclined }\end{array}$ & $\begin{array}{c}\text { More } \\
\text { inclined }\end{array}$ & $\begin{array}{c}\text { No } \\
\text { change }\end{array}$ & $\begin{array}{c}\text { Less } \\
\text { inclined }\end{array}$ & $\begin{array}{c}\text { Much less } \\
\text { inclined }\end{array}$ \\
1 & 2 & 3 & 4 & 5 \\
\hline
\end{tabular}

